\title{
O espaço das classes sociais no Brasil
}

Edison Ricardo Bertoncelo

Introdução

Na sociologia brasileira há, ao menos, três conjuntos razoavelmente bem delimitados de estudos de classe. Existem aqueles informados pelas perspectivas neoweberiana e neomarxista, que enfocam a construção de esquemas de posições de classe, com base em critérios objetivos, teoricamente fundamentados e definidos a priori, a fim de investigar os efeitos das relações de classe sobre as chances de vida dos indivíduos (Ribeiro, 2011; Santos, 2011).

Diferentemente, há outro conjunto de estudos, marcados por um estilo de investigação sociológica que enxerga nas classes sociais agentes coletivos de contestação e/ou transformação da ordem social vigente. São estudos moldados pela tradição marxista, que trazem ao centro da investigação a tentativa de articular economia e política, ou seja, os processos políticos, de um lado, e a ação e os interesses das classes sociais, de outro (Boito Jr. e Galvão, 2007).

Por fim, alguns estudos privilegiam a investigação dos modos de existência e de reprodução das classes entendidas como coletividades sociais, tendo como principal influência a obra de Pierre Bourdieu. O termo "coletividades sociais" sublinha que as classes sociais, como conjunto de posições relativas nos planos material e simbólico/ cultural, fixam balizas à sociabilidade cotidiana e conformam estilos de vida (Souza, 2012; Pulici, 2011).

O estudo de classe aqui proposto insere-se nessa última perspectiva, e seu objetivo principal é reconstruir o espaço das classes sociais no Brasil. Na próxima seção, faço 
uma brevíssima exposição dos principais aspectos da perspectiva bourdieusiana para o estudo das classes sociais. A seguir, descrevo as bases de dados em que a análise empírica se apoia e, então, passo à interpretação dos principais resultados empíricos.

Espaço social e relações de classe

Pode-se dizer que a perspectiva bourdieusiana oferece, ao menos, três contribuições para o estudo das classes sociais:

1. A concepção da sociedade como um espaço multidimensional de posições sociais. Entendida a sociedade dessa forma, os agentes sociais ocupam posições relativas distintas, definidas conforme se distribuem as propriedades entre eles, o que lhes confere poder nas relações com os outros. Tais propriedades são recursos de poder e referem-se a distintas formas de capital (econômico, cultural, social e simbólico). Em sociedades capitalistas, diversos estudos têm mostrado que a distribuição dessas propriedades tende a ser estruturada em três dimensões: volume e composição do capital (peso relativo das diferentes formas de capital - dimensões sincrônicas) e trajetória (referente à evolução da estrutura do capital no tempo - dimensão diacrônica) (Bourdieu, 2008). Os agentes que ocupam posições relativas vizinhas no espaço social dessas dimensões fazem parte de uma mesma classe objetiva (ou "classe no papel"), mas que também é uma classe provável, porque, estando tais agentes sujeitos às mesmas condições sociais e a seus condicionamentos, têm maior probabilidade de internalizarem disposições similares para agir e, portanto, terem tomadas de posição semelhantes (Bourdieu, 1987).

2. A concepção do habitus como uma estrutura que medeia posiçôes objetivas e práticas sociais. O habitus, como um sistema de disposições duráveis e transponíveis, uma espécie de "esquema generativo" que orienta a prática nos campos em que a vida social se organiza, resulta da incorporação das condições de existência associadas aos diferentes conjuntos de posições no espaço social definidas em termos de suas propriedades relacionais e intrínsecas (Bourdieu, 2007).

3. A concepção das classes como coletividades sociais, cujas fronteiras são continuamente desenhadas, contestadas e reproduzidas na prática social. Como resultado da dupla capacidade do habitus de produzir práticas e juízos sobre as práticas, emerge uma homologia entre posições (ou distâncias) no espaço social e posições no espaço simbólico ou dos estilos de vida, que são, então, retraduções simbólicas - na lógica dos diferentes campos - de diferenças objetivas. 
Em suma, o modelo teórico proposto por Bourdieu implica a sobreposição de três esquemas analíticos: o espaço social, o habitus e o espaço dos estilos de vida, sendo o habitus o elemento que medeia a transmutação das diferenças objetivas em signos distintivos. Vê-se, assim, que o espaço social é, simultaneamente, uma estrutura de relações objetivas, que está na origem dos esquemas de percepção, classificação e ação que orientam a prática, e um conjunto de lugares estratégicos a partir dos quais os agentes lutam em torno da apropriação (e valorização) do capital e da imposição de princípios de classificação e de (di)visão do mundo.

Em outras ocasióes (Bertoncelo, 2013, 2015), tive a oportunidade de explorar empiricamente o argumento sobre as homologias entre o espaço social e o espaço simbólico. Neste estudo, meu objetivo é outro: reconstruir o espaço social, ou seja, o espaço das diferenças e das desigualdades sociais que constitui a base objetiva para a formação das classes como coletividades sociais (Flemmen, 2013).

\section{Dados e métodos de análise}

Os dados utilizados neste estudo foram extraídos da pesquisa Dimensões Sociais da Desigualdade. Conduzida em 2008, essa pesquisa baseou-se na aplicação de questionários estruturados a chefes e cônjuges em mais de 8 mil domicílios, amostra representativa da população brasileira urbana e rural, com exceção da área rural da região Norte. A pesquisa teve como objetivo principal observar diversos aspectos das condições de vida dos moradores. Os dados revelaram-se bastante úteis para o objetivo deste estudo, ainda que não tenham sido construídos a partir da problemática que o orienta. Particularmente importantes, as informações disponíveis nesse banco de dados nos permitirão construir indicadores razoavelmente válidos de diferentes tipos de capital (econômico, cultural e social) acumulados nos domicílios, de um ponto de vista sincrônico e diacrônico.

O método de análise dos dados é a ACM (Análise de Correspondências Múltiplas). Esta é uma técnica estatística bastante útil para revelar padrões subjacentes à distribuição de dados categóricos. Partindo de uma tabela em que as linhas representam os casos e as colunas, as respostas a questões ou a itens de um questionário (modalidades), "a ACM examina as relações entre as diferentes modalidades e identifica os eixos que as separam relacionalmente [...] de forma a traçar a distância simbólica entre elas" (Bennett et al., 2009, p. 46, tradução minha). As variáveis e suas modalidades são inseridas no modelo como ativas e suplementares. As variáveis ativas e suas modalidades são consideradas no cálculo das distâncias relativas e da orientação dos eixos para a construção do espaço de correspondências. As variáveis e as modalidades inseridas como suplementares servem apenas como subsídio para a interpretação dos resultados. 
Inserimos como variáveis e modalidades ativas alguns itens do questionário (propriamente recodificados, quando necessário) que podem servir como indicadores da posse/controle de tipos de capital econômico e cultural pelos domicílios (ver em apêndice Tabela 1). As variáveis e as modalidades que se referem ao capital social são incluídas como suplementares. Sublinho que todos os indicadores construídos se referem ao domicílio (unidade de análise) ${ }^{1}$. Como mostra fartamente a literatura sobre estratificação social, as estratégias de reprodução ou de mobilidade social são levadas a cabo por famílias e indivíduos dentro de domicílios a partir dos recursos (materiais e imateriais) neles acumulados. Destaco, ainda, que foram construídas medidas de classe ocupacional do domicílio (que tomam informações sobre a ocupação do chefe como proxy e, quando inexistentes, as do cônjuge) e de sua origem (elaboradas a partir de informações das ocupações do pai do chefe e, quando ausentes, daquelas da mãe do chefe e, se inexistentes em ambos os casos, pai ou mãe do cônjuge $)^{2}$. Decidiu-se por inserir os indicadores de classe ocupacional (para domicílio e sua origem) como modalidades ativas para minimizar os riscos de uma construção excessivamente redutora do espaço social a um conjunto de posições determinado pela distribuição de múltiplas formas de capital, negligenciando o entendimento das classes como relações ou processos causais que têm sua origem nos processos produtivos e nas relações de mercado. De fato, o que se tentou fazer foi aproveitar as potencialidades das teorias de classe marxista e weberiana, para as quais as sociedades capitalistas estão organizadas em torno de divisões de classe estruturalmente ligadas ao funcionamento da economia, com os insights da teoria bourdieusiana, sobretudo sua ênfase sobre a multidimensionalidade das relaçôes de classe (Flemmen, 2013)3.

Análise e interpretação dos dados: reconstrução do espaço das classes sociais no Brasil

Os resultados produzidos pela ACM identificam eixos que separam relacionalmente as modalidades das variáveis ativas. Os eixos são retidos para interpretação em razão da proporção da variância total "explicada” e de serem significativos do

1. Para auxiliar na interpretação dos resultados, são incluídos como suplementares os indicadores que mensuram os atributos de chefe e/ou cônjuge separadamente.

2. São incluídas medidas de classe ocupacional do cônjuge e do pai/mãe do cônjuge (assim como dos melhores amigos do chefe e/ou do cônjuge) como variáveis suplementares. Consideramos aqui apenas os casos em que foi possível identificar o pertencimento de classe ocupacional do domicílio (4.961 casos).

3. As categorias de classe ocupacional são aqui construídas em parte levando em conta os critérios teóricos usados nos estudos de inspiração neomarxista e neoweberiana conduzidos no Brasil, que consideram o controle de ativos de capital, qualificação e de organização (por exemplo, frações proprietárias, dirigentes, gerenciais, especializadas etc.) e/ou as relações de emprego (exemplos: ocupações não manuais versus ocupações manuais, rurais versus urbanas). 
ponto de vista teórico (Le Roux; Rouanet, 2010). Em função desses critérios, são considerados três eixos que "explicam", respectivamente, $88 \%$, 7\% e 3\% da variância total. A relevância heurística do primeiro eixo deve-se à natureza das variáveis e dos indicadores construídos, que se referem à posse/controle de tipos de capital econômico e cultural. A possibilidade de construir indicadores que apreendessem diferenças qualitativas provavelmente elevaria a pertinência heurística dos demais eixos de interpretação.

O primeiro eixo apreende a dimensão referente ao volume de capital econômico e cultural possuído pelos domicílios (nas dimensões sincrônica e diacrônica), demarcando uma região superior de uma inferior do espaço social. Tal eixo opõe as regióes mais destituídas de capital (recursos relevantes nos principais jogos de competição social, como o mercado de trabalho, mercado escolar, mercado matrimonial etc.) às regiões mais qualificadas em termos desses mesmos capitais.

$\mathrm{Na}$ parte superior do referido eixo (Figura 1), encontram-se as modalidades indicativas de niveis relativamente elevados de capital econômico e cultural (por exemplo, escolaridade máxima do domicílio alcançando o ensino superior completo), sincrônica e diacronicamente. Nessa região, vemos também as modalidades indicativas de origens relativamente privilegiadas em termos de pertencimento de classe ocupacional, acumulação de patrimônio e de capital escolar (origem entre profissionais e empregadores urbanos). Na parte inferior do referido eixo, estão as modalidades indicativas de destituição relativa de capitais econômico e cultural, inclusive na origem do domicílio.

O segundo eixo, que "explica” cerca de $7 \%$ da variância, também apreende uma dimensão referente ao volume de capital, mas demarca uma região intermediária do espaço social das regiões superior e inferior. Tal eixo opõe as categorias não manual de rotina e manual mais qualificada (incluindo supervisores de trabalho manual), que ocupam a região intermediária em relação ao primeiro eixo e à esquerda do segundo eixo, às categorias de trabalhadores manuais menos qualificadas, autoempregados precários e trabalhadores agrícolas e às frações profissionais, dirigentes e proprietárias, que ocupam a região intermediária superior em relação ao primeiro eixo e à direita do segundo eixo (ver Figura 1). A região ocupada pelas frações não manuais e manuais mais qualificadas é caracterizada fortemente pela posse de niveis médios de capital cultural (sobretudo em termos de credenciais escolares - ensino médio completo -, cursos de computação e profissionalizante). Além disso, têm contribuições significativas para esta "porção" do eixo as modalidades indicativas de origem um pouco mais qualificada (como chefe e/ou cônjuge com origem entre trabalhadores manuais qualificados) e as da posse de algum capital econômico (por exemplo, domicílios que contam com renda total per capita entre dois e três salários-mínimos). 


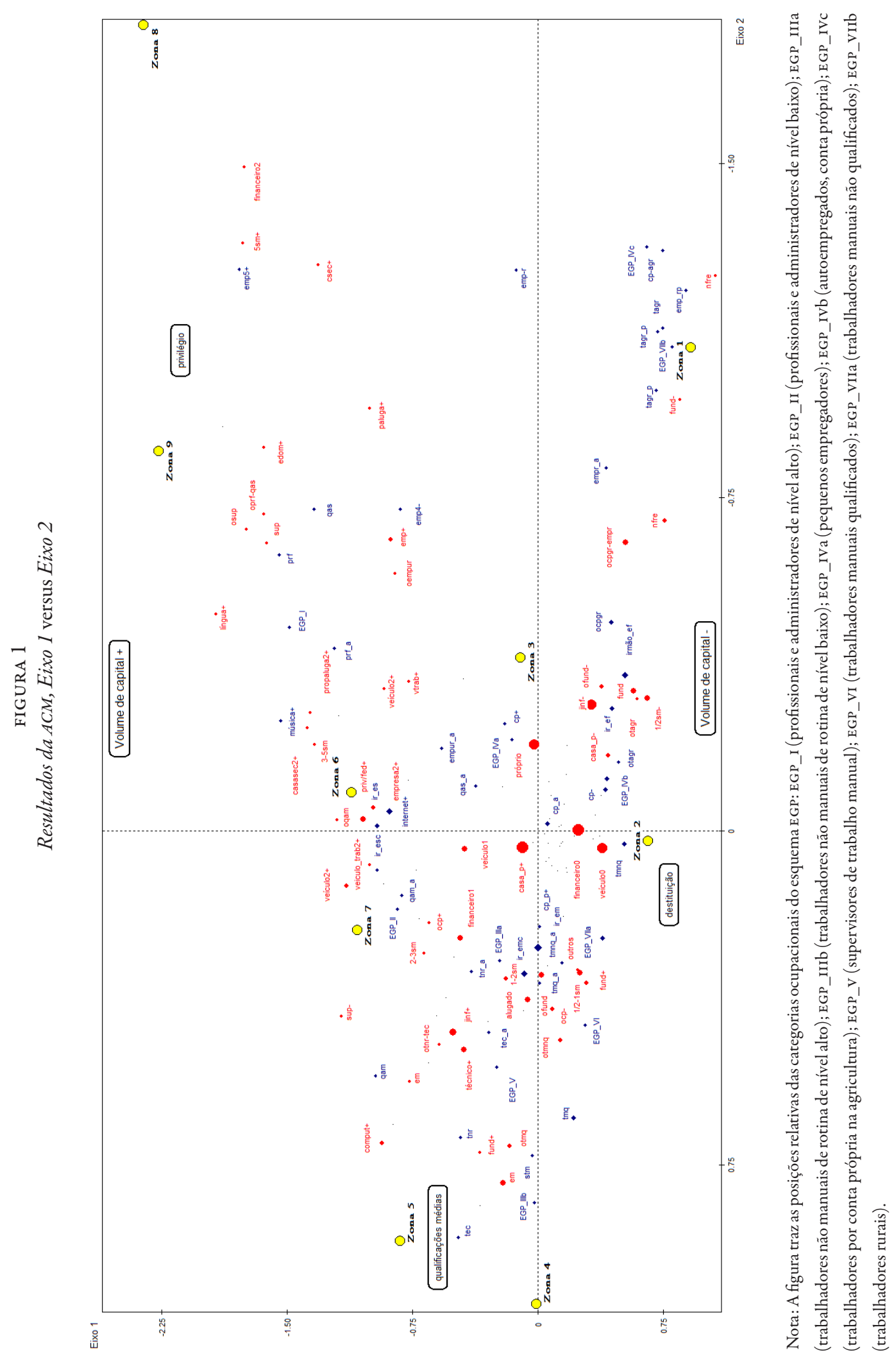


Portanto, os dois primeiros eixos distinguem muito claramente uma região intermediária do espaço social de uma região "superior", como veremos, dinamizada em torno da reprodução do privilégio (em termos de origem muito qualificada e da forte patrimonialização da riqueza), e de uma região inferior, estruturada muito fortemente pela desqualificação e destituiçãa em relação aos capitais relevantes nos jogos de concorrência social.

O terceiro eixo, que explica uma porção quase insignificante da variância dos dados (3\%), é aqui considerado por sua importância teórica: apreende as dimensões da composição do capital e de suas modalidades típicas de apropriação (trajetórias modais). Assim, à direita do referido eixo (Figura 2), estão as modalidades indicativas da posse deniveis elevados de capital econômico (sobretudo em termos de patrimônio, domicílios que contam com uma casa secundária, ou uma propriedade para alugar $)^{4}$, que estão correlacionadas com as modalidades indicativas de pertencimento e de origem de classe ocupacional dos domicílios nas frações da pequena e média burguesia urbana (proprietária ou não). Diferentemente, à esquerda do eixo, estão as modalidades indicativas da posse de niveis mais elevados de capital cultural (sobretudo de capital escolar) e de domicílios com pertencimento e origem de classe ocupacional nas frações profissionais/dirigentes e gerenciais.

Esta é uma interpretação preliminar de caracterização do espaço social, que pode ser complementada por um exercício de classificação dos agentes por meio de uma técnica de classificação hierárquica (tipo de análise de cluster). Este exercício nos permitirá delimitar zonas no espaço social que incluem conjuntos de domicílios com "perfis similares" na distribuição das propriedades relacionais (múltiplas formas de capital) aqui consideradas. A combinação da ACM com a análise hierárquica de cluster tem se revelado muito útil para operacionalizar uma concepção relacional do espaço social que privilegia uma estratégia indutiva de delimitação das fronteiras de classe pela distribuição de suas propriedades relevantes (Roose et al., 2012).

A escolha se deu por repartir o espaço social em nove zonas, de forma a conferir alguma diversidade a suas regiões inferior, intermediária e superior (Figura 1) 5 . O termo zona foi escolhido aqui, seguindo a indicação de Virgílio Pereira (2005), para minimizar os riscos de uma leitura substancialista dos resultados empíricos reportados e também para alertar sobre os riscos do uso de classificações excessivamente gerais (por exemplo, "camadas populares" ou "classes médias"), que não atentam para as diferenciações existentes dentro de uma mesma região do espaço

4. Os dados não trazem informações sobre o valor do patrimônio, localização, modos de fruição.

5. A escolha de quantos clusters reter baseou-se na observação do dendograma (Figura 3), na análise dos valores da inércia entre e dentro de cada agrupamento e na interpretação teórica. 
O espaço das classes sociais no Brasil, pp. 73-104

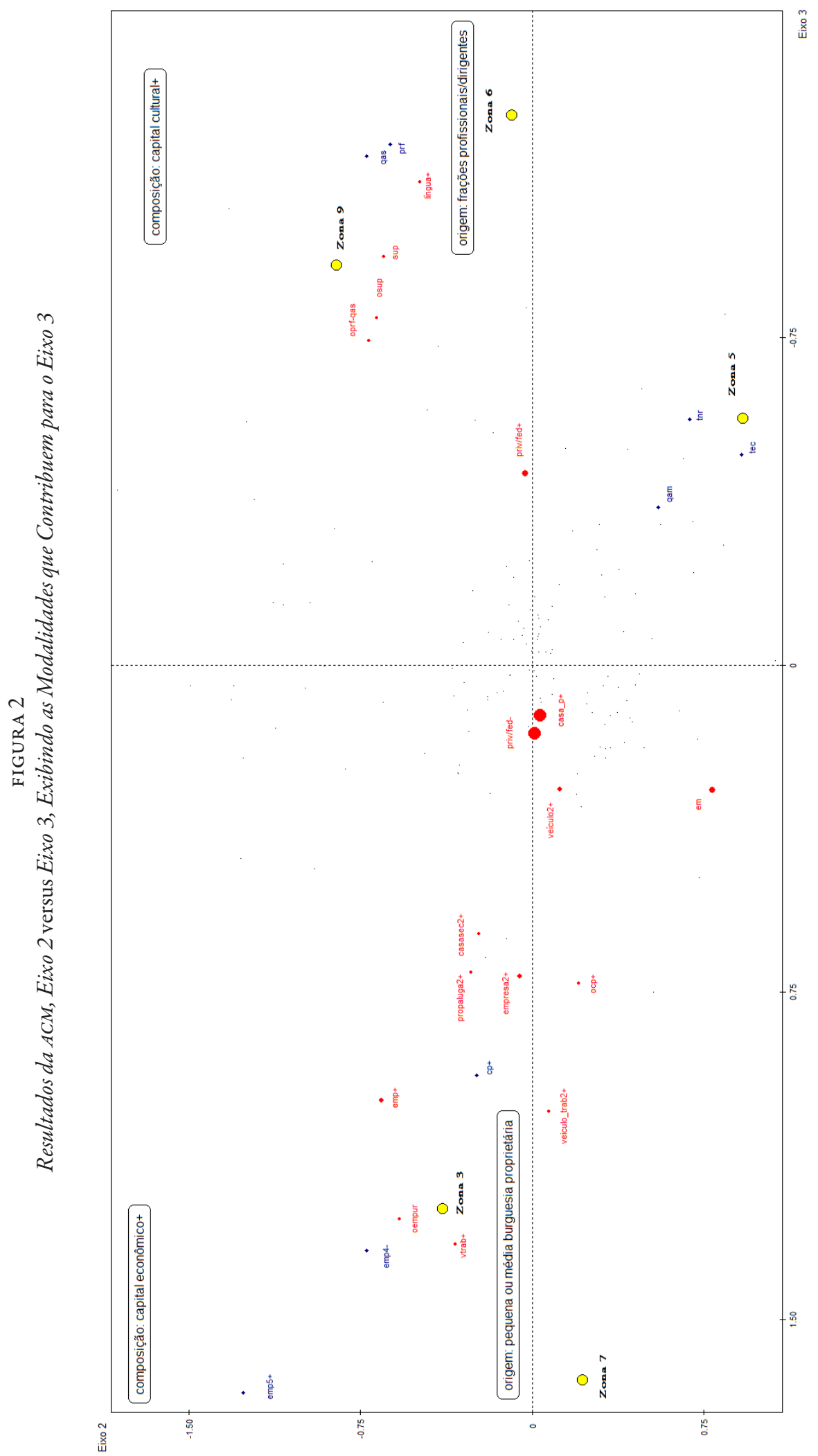




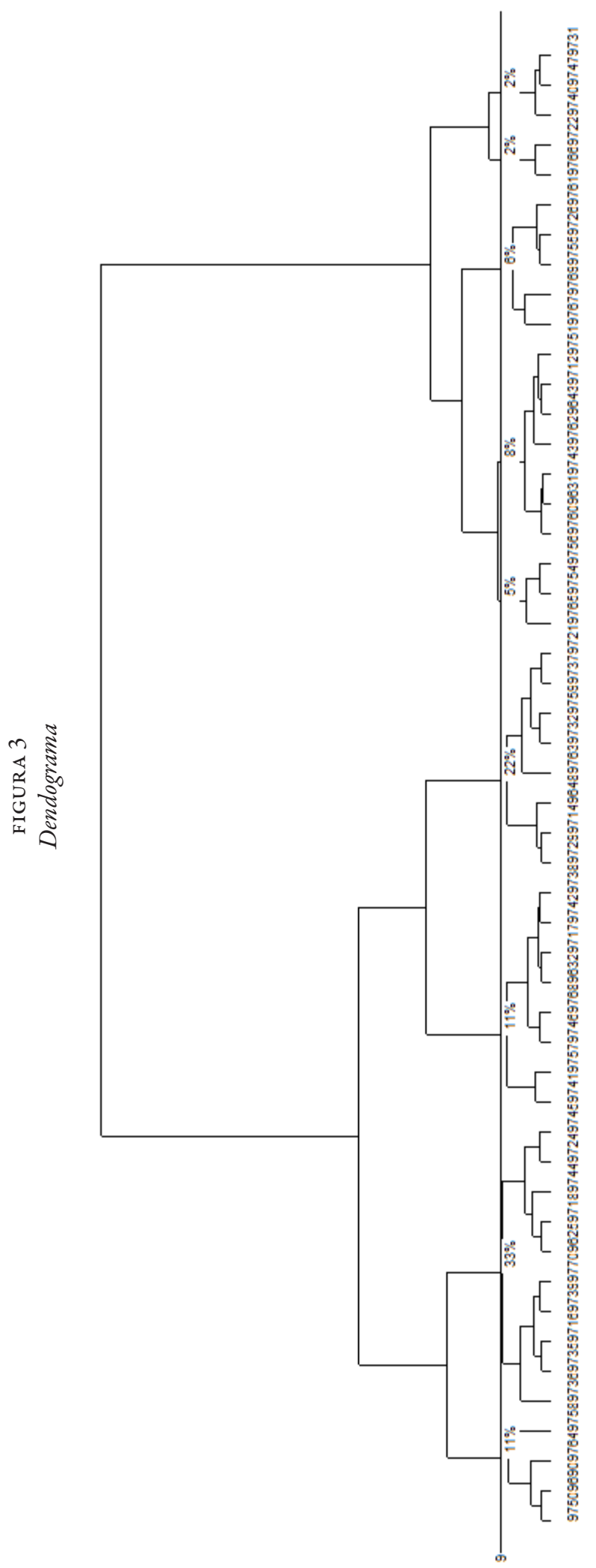


social. Trata-se aqui tão somente de fazer uma leitura exploratória das fronteiras que possivelmente delimitam "porções" do espaço social e que podem constituir, portanto, lugares estratégicos a partir dos quais os agentes lutam pela apropriação de capital e pela imposição dos princípios de classificação das práticas ${ }^{6}$.

\section{Zona 1 - Trabalhadores e autoempregados no campo: fragilização e destituição econômica e cultural}

A zona 1, no canto inferior direito do espaço social, caracteriza-se por incluir cerca de $15 \%$ dos domicílios (17\% dos indivíduos) da amostra e está estruturada em torno de um pertencimento de classe muito particular, abrigando quase $85 \%$ dos trabalhadores e autoempregados agrícolas da amostra, além de $78 \%$ daqueles que têm origem nessas mesmas categorias, com uma proporção elevada de pardos. Cerca de $50 \%$ dos domicílios nela localizados são chefiados por trabalhadores ou autoempregados do campo (há uma proporção igualmente elevada de cônjuges nesses agregados ocupacionais) e quase $40 \%$ deles, por trabalhadores manuais não qualificados ou autoempregados precários ${ }^{7}$. Esta zona do espaço social é também caracterizada por forte estratificação dos padrões de sociabilidade: 70\% dos chefes que declararam que seu melhor amigo é um trabalhador agrícola estão aí localizados (há proporções igualmente elevadas de pardos entre os melhores amigos de chefes e cônjuges).

Trata-se de uma zona cujos domicílios são caracterizados pelo forte envelhecimento relativo e possivelmente pela dificuldade de reprodução social, evidenciados pela presença de muitos chefes e cônjuges com mais de 55 anos de idade $(38,2 \%$ ante $21,6 \%$ na amostra). Ademais, esta zona caracteriza-se pela quase completa destituição dos capitais econômico e cultural (conforme as modalidades indicativas utilizadas neste estudo). Em 57\% dos domicílios, os pais do chefe e/ou do cônjuge não frequentaram escola e, em cerca de $65 \%$ deles, a escolaridade máxima alcançada pelo chefe e/ou pelo cônjuge não passou do primário completo (quatro anos de estudo ou menos). É muito rara também a presença de algum capital cultural nesses domicílios, conforme os indicadores selecionados: somente em $6 \%$ desses domicílios é possível encontrar um chefe e/ou cônjuge que já tenha feito ou esteja fazendo um curso profissionalizante (essa proporção é quase nula para cursos de computação, línguas ou de música). Menos de $4 \%$ dos domicílios localizados nesta zona do espaço social possuem computador com conexão à internet.

6. A caracterização das zonas será feita com base na leitura dos valores-t ( $t$-values), que levam em conta as diferenças entre as proporções de uma modalidade em um agrupamento (zona) e sua distribuição na amostra.

7. Esta informação evidencia que as zonas são constituídas em torno de um conjunto de propriedades relacionais, não se reduzindo à classe ocupacional. 
Além disso, esses domicílios apresentam valores baixos no índice construído para mensurar a posse de eletrodomésticos e eletrônicos ( $70 \%$ ante $37 \%$ na amostra) ${ }^{8}$ e se caracterizam pela ausência de rendimentos financeiros de qualquer natureza e por renda per capita total de até $1 / 2$ salário-mínimo ( $61 \%$ ante $28 \%$ no total). Esses números tornam-se ainda mais significativos quando consideramos a elevada proporção de domicílios na zona do espaço social (30\%) em que há algum tipo de rendimento derivado de políticas públicas (bolsa-família, bolsa-moradia etc.) ${ }^{9}$. Apenas 20\% desses domicílios possuem algum veículo de passeio (carro ou moto) e menos de $2 \%$ possuem veículo de trabalho. Ou seja, trata-se de uma zona do espaço social que abriga domicílios com baixíssima capitalização.

A quase completa destituição de capitais econômico e cultural é apenas contrabalançada pelo fato de que, em quase $80 \%$ deles, o chefe é proprietário da residência; porém, em mais de $50 \%$ dos casos, o estado de conservação da habitação é, no máximo, regular (conforme a classificação da pesquisa). A maior parte dos domicílios são casas (95\%) localizadas em ruas não asfaltadas. Há uma proporção elevada no que diz respeito à amostra de domicílios polinucleares (com mais de um núcleo familiar), com ou sem cônjuge, e de famílias monoparentais, com um peso desproporcional de domicílios com seis ou mais moradores e com alta fecundidade (quatro filhos ou mais, em $45 \%$ deles, ante $20 \%$ na amostra).

\section{Zona 2 - As frações manuais urbanas destituídas e fragilizadas}

Esta zona, que inclui cerca de 30\% dos domicílios (e 31\% dos indivíduos) da amostra, é ocupada predominantemente (em cerca de $75 \%$ dos casos) por domicílios formados por trabalhadores manuais não qualificados e autoempregados com pouca ou nenhuma capitalização (os autoempregados precarizados - Santos, 2002), nos quais predominam os trabalhadores da construção civil (pedreiros, pintores, eletricistas, serventes) e dos serviços pessoais (empregadas domésticas). Há uma presença relativa bastante forte de domicílios com famílias monoparentais (18\%), chefiados por mulheres (em quase 30\%) e com mais de um núcleo familiar sem o cônjuge.

Como a anteriormente descrita, esta zona possui elevado grau de homogeneidade quanto a alguns aspectos da sociabilidade e interação social, ao menos quando observados a partir das informações sobre a classe ocupacional do cônjuge e a do

8. O índice é o resultado recodificado da soma ponderada da presença dos seguintes itens no domicílio: geladeira, fogão, rádio, máquina de lavar, telefone fixo, telefone celular, televisão, $\mathrm{CD} / \mathrm{DVD}$ player, micro-ondas, computador, ar condicionado, TV a cabo.

9. As informações no banco incluem rendimentos derivados de abono, permanência, seguro de vida, bolsa-família etc. 
melhor amigo do chefe e/ou do cônjuge. Entre os cônjuges com ocupação, 75\% são também trabalhadores manuais não qualificados ou autoempregados precários (ante 43\% na amostra). Além disso, proporções similares (mais de 50\%) de chefes e cônjuges têm como seus melhores amigos indivíduos que pertencem a esses mesmos agregados ocupacionais. Predominam, entre os melhores amigos, os pretos e pardos, perfil que também caracteriza chefes e cônjuges dos domicílios nessa zona (60\% dos chefes; $44 \%$ dos cônjuges).

Verifica-se, ainda, um elevado grau de reprodução social nessa zona do espaço social: quase $40 \%$ dos domicílios são habitados por indivíduos cuja origem social é bastante similar à posição que ocupam atualmente. Os chefes são geralmente filhos de trabalhadores manuais não qualificados (20\%) ou de autoempregados (21\%) - as proporções para os cônjuges são, respectivamente, 20\% e 17\%. Há uma proporção igualmente significativa de domicílios cujo chefe/cônjuge é filho(a) de trabalhadores ou autoempregados rurais (38\%).

Os domicílios dessa zona são também caracterizados pela destituição em relação à posse ou ao controle de capitais relevantes, embora em situação relativamente melhor do que os domicílios inseridos na zona do espaço social anteriormente descrita. Em termos de capital escolar, há uma proporção significativa de domicílios (62\%) com escolaridade máxima restrita ao ensino fundamental (antigo ginásio) incompleto e uma proporção bem menor de domicílios cuja escolaridade máxima alcança o ensino fundamental completo (27\%). O baixo capital escolar do domicílio reproduz o baixo capital escolar "herdado": quase 30\% dos domicílios têm, em sua origem, pais com, no máximo, o (antigo) primário completo (53\%). A destituição de capital escolar estende-se aos irmãos do chefe e do cônjuge: $43 \%$ dos irmãos ou irmãs dos chefes de domicílio possuem, no máximo, o ensino fundamental e apenas $5 \%$ dos irmãos ou irmãs dos chefes e/ou cônjuges em tais domicílios possuem o ensino superior. É bem provável que essa situação de destituição de capital escolar se estenda à geração mais nova: em somente $4 \%$ dos domicílios há algum filho no ensino superior e a grande maioria deles estuda em escola pública (nas redes estadual e municipal), o que evidencia a baixa capacidade relativa de investimento das famílias desses domicílios na escolarização dos filhos ${ }^{10}$. Em termos de outros indicadores de capital cultural, os domicílios localizados nessa zona possuem escores baixos em qualquer de suas modalidades indicativas aqui consideradas: são raríssimos os domicílios em que o chefe e/ou o cônjuge fizeram ou fazem cursos de computação (2\%), profissionalizante (16\%), de línguas $(0,5 \%)$ ou de música $(0,5 \%)$.

10. Há informações apenas sobre os filhos que residem no domicílio. 
Essa descrição de destituição quase completa em relação a modalidades de capital cultural (sobretudo de credenciais escolares) aplica-se, de forma similar, às modalidades de capital econômico: a maioria dos domicílios aqui localizados possui renda per capita de até um salário-mínimo (70\%), não possui veículo de passeio (78\%) ou de trabalho (98\%), rendimentos financeiros (85\%) ou computador conectado à internet (90\%). Ademais, tais domicílios apresentam escores relativamente baixos no índice construído para mensurar a posse de eletrodomésticos ou eletrônicos pela(s) família(s) residente(s): mais de $50 \%$ possuem valor baixo ou médio-baixo nesse índice. A destituição de capital econômico reproduz fortemente as condições associadas à origem do domicílio.

As condições de habitação são muito precárias: 59\% das habitações dessas famílias são classificadas como ruins ou regulares e quase 70\% delas possuem, no máximo, três cômodos ${ }^{11}$, o que é muito significativo, uma vez que esses domicílios tendem a possuir elevada fecundidade (em $25 \%$ deles, quatro filhos ou mais) e uma quantidade relativamente grande de moradores. Em 20\% dos casos, os domicílios habitados pelas famílias foram cedidos ou invadidos (ante 11\% na amostra) e, em 58\% deles, os domicílios ocupados pertencem às famílias residentes (ante 65\%). Predominam casas (91\%) como tipo de habitação, com presença relativamente elevada em favelas.

\section{Zona 4 - Operariado qualificado e estabelecido}

Vimos que as duas zonas localizadas na região inferior do espaço social, em que se situam os domicílios mais destituídos de capitais relevantes nos principais jogos de concorrência social, perfazem cerca de $45 \%$ dos domicílios da amostra. Talvez esta seja a peculiaridade do espaço das classes sociais no Brasil em comparação com sociedades capitalistas avançadas: as regiões do espaço social marcadas pela destituição e desqualificação abrigam uma proporção relativamente muito significativa de individuos e familias.

A zona que descreverei a seguir também ocupa uma "porção" da região inferior do espaço social, mas se localiza mais acima do que as descritas anteriormente ${ }^{12}$. Está, digamos, em uma região intermediário-inferior, que inclui cerca de $21 \%$ dos domicílios (e indivíduos) amostrados. Essa zona é fortemente estruturada em torno do pertencimento às frações assalariadas de trabalhadores manuais qualificados e de

11. A quantidade de cômodos é usada como indicador do tamanho e das condições de conforto da habitação.

12. Esta zona é fortemente conformada pelas oposições relativas ao eixo 2, que distingue uma região intermediária do espaço social de suas regiões superior e inferior, em termos do volume de capital. 
supervisores de trabalho manual (operariado industrial, motoristas, mecânicos), que, juntas, perfazem mais de $40 \%$ dos domicílios. Outros 20\% são chefiados por trabalhadores não manuais de rotina (sobretudo de menor qualificação) e por técnicos de nível médio. Essa relativa heterogeneidade depertencimentos de classe ocupacional evidencia o quanto a fronteira entre trabalho manual e não manual é fluida. Outra propriedade que estrutura fortemente essa zona é a maior disposição de credenciais escolares quando comparada às zonas antes descritas: em quase $73 \%$ desses domicílios, a escolaridade máxima alcança o ensino médio completo.

Destaco, ainda, a relativa homogeneidade social no recrutamento que caracteriza essa zona do espaço social: há proporções elevadas de chefes de domicílios com origem nas frações mais qualificadas (26\%; entre cônjuges, $18 \%$ ) e menos qualificadas (40\%) de trabalhadores manuais urbanos e rurais (sobretudo entre autoempregados, 15\%; entre os cônjuges, 18\%), evidenciando um processo de mobilidade razoável mas restrito às regióes inferiores e intermediário-inferior do espaço social, estruturadas em torno do pertencimento às classes manuais urbanas e rurais, alcançando, por vezes, as franjas inferiores do trabalho não manual ${ }^{13}$. Em outras palavras, essa zona abriga domicílios ocupados por operários estabelecidos e outros ascendentes a partir de frações relativamente mais destituídas e desqualificadas e também domicílios em que o movimento de ascensão ultrapassou a barreira do trabalho manual, ainda que por uma pequena margem.

Em termos da posse de capital escolar, como vimos antes, essa zona é caracterizada por domicílios com credenciais escolares relativamente raras nas regióes inferiores do espaço, mas ainda pouco valorizadas nos principais jogos de concorrência social (Ribeiro, 2011). Essas vantagens quanto à posse de credenciais escolares reproduzem, em parte, origens sociais relativamente menos destituídas nesse sentido: em $42 \%$ dos domicílios, a escolaridade máxima na origem alcança, ao menos, o ensino fundamental (ginásio) completo (em 20\% deles, o ensino médio). Tais vantagens refletem-se, ainda, na presença significativa de irmãos e/ou irmãs do chefe (56\%) e/ ou do cônjuge (42\%) nesses domicílios com o ensino médio completo ${ }^{14}$. Quanto aos outros indicadores de capital cultural, os domicílios reunidos nessa zona apresentam escores igualmente médios: em 45\% deles (segunda proporção mais elevada), o chefe e/ou o cônjuge fizeram ou fazem algum curso profissionalizante, curso de computação (em 26\% deles) ou pré-escola ou jardim de infância (60\%). No entanto,

13. Essas evidências corroboram os resultados dos estudos de mobilidade social no Brasil, que indicam a existência de um padrão de elevada mobilidade (em termos de fluxo) mas de curta distância (Scalon, 1999; Ribeiro, 2012).

14. Os dados entre parênteses referem-se à proporção de domicílios na zona em que chefe ou cônjuge têm ao menos um irmão que alcançou certo nível de escolaridade. 
ainda são raros os domicílios em que o chefe e/ou o cônjuge estudaram em escolas privadas ou federais (15\%), fizeram ou fazem curso de idiomas (2\%) e aqueles em que há filhos com ensino superior (6\%).

A relativa homogeneidade em termos de recrutamento social reflete-se na conformação dos padrões de sociabilidade e interação: $40 \%$ dos chefes mencionam que seus melhores amigos estão nas frações mais e menos qualificadas do trabalho manual. Entre os cônjuges, há uma proporção maior de melhores amigas entre trabalhadores não manuais de rotina, o que provavelmente revela o forte caráter de gênero dessas ocupações (Scalon, 2013). Quanto à classe ocupacional do cônjuge, predominam os pertencimentos às frações manuais menos qualificadas de trabalhadores manuais (16\%), mais qualificados (6\%) e também às frações não manuais de rotina $(15 \%)^{15}$.

Quanto à posse de capital econômico, os domicílios incluídos nessa zona do espaço social apresentam condições materiais mais seguras, mas ainda assim marcadas por uma situação de relativa destituição: quase $90 \%$ dos domicílios têm renda total de até dois salários-mínimos per capita, são relativamente menores e com menos filhos (padrão de fecundidade restrito a dois filhos é bastante comum). A baixa fecundidade é provavelmente reveladora de estratégias familiares orientadas para a ascensão social das gerações mais novas. A condição de conservação do domicílio é boa, na maioria dos casos, mas também é muito comum a existência de famílias que residem em domicílios alugados (34\% contra $24 \%$ na amostra). Uma porção significativa deles possui algum tipo de rendimento financeiro (30\%) e um escore médio-alto no índice que mesura a posse de eletrodomésticos e eletrônicos (27\%). No entanto, há uma proporção relativamente elevada de famílias cujas habitações têm, no máximo, dois cômodos (32\%) e que carecem de computador com conexão à internet (78\%).

\section{Zona 3 - Pequena burguesia capitalizada e envelhecida}

As três zonas anteriormente descritas do espaço social incluem mais de 65\% dos domicílios amostrados (e uma proporção similar de indivíduos). A zona que descreverei a seguir, que inclui cerca de 10\% dos domicílios (e 9,5\% dos indivíduos), difere significativamente das anteriores ${ }^{16}$. Ela se caracteriza por domicílios constituídos por frações da pequena burguesia urbana (empregadores com menos de quatro empregados, ou autoempregados), dotadas de niveis relativamente elevados de capital econômico e relativamente baixos de capital cultural: $52 \%$ dos domicílios são chefiados

15. Nos casos em que chefe e cônjuge têm ocupação, o domicílio modal é aquele chefiado por um trabalhador qualificado, sendo o cônjuge um trabalhador manual não qualificado urbano.

16. Esta zona - ao lado das zonas 6,7 e 9 (Figura 2) - é fortemente conformada pelo terceiro eixo, cujas oposições incidem na composição e nas modalidades de apropriação do capital. 
por autoempregados capitalizados (contra 9,4\% na amostra); $11,2 \%$, por pequenos empregadores urbanos (contra 1,5\%); 4,2\%, por médios empregadores urbanos (contra $1,2 \%)$, tipicamente brancos (51\%) com mais de 45 anos de idade (63\%).

Quanto aos padrões de sociabilidade, há relativa homogeneidade quanto ao pertencimento de classe do cônjuge (proporções elevadas de autoempregados e pequenos empregadores) e forte homogeneidade em relação ao pertencimento de classe do melhor amigo do chefe ( $40 \%$ são também autoempregados), o que se repete, em menor medida, com o cônjuge (27\% dos melhores amigos do cônjuge são, também, autoempregados) e, também, em relação à cor (proporções elevadas de melhores amigos brancos).

O recrutamento a essa zona do espaço social é provavelmente produto da combinação de estratégias de reprodução social e de acumulação de capital, sobretudo de tipo econômico: há uma proporção relativamente elevada de chefes com origem na mesma classe ocupacional ( $21 \%$ ante $7 \%$ na amostra) ou com origem nas frações mais qualificadas de trabalhadores manuais (30\% ante 13\%) e de cônjuges com origem na fração relativamente menos capitalizada de autoempregados ( $23 \%$ ante $16 \%$ ) ou mais qualificada de trabalhadores manuais (21\%).

Tais domicílios apresentam escores relativamente altos nos indicadores de capital econômico incluídos neste estudo: $31 \%$ deles têm veículo de trabalho; em 78\%, a residência é própria; $71 \%$ deles possuem boa condição de preservação e $23 \%$ possuem cinco cômodos ou mais. Diferentemente dos domicílios das zonas antes descritas, há aqui uma proporção relativamente elevada de apartamentos (31\%) e de habitações em condomínios (38\%). Há proporções acima da média de domicílios em que algum de seus residentes possui uma casa secundária (14,5\% ante 5,8\% na amostra) ou uma propriedade para alugar (15\% ante 5,9\%), o que evidencia a existência de estratégias de patrimonialização do capital ${ }^{17}$, proporções igualmente elevadas de domicílios com escores médio-alto e alto no índice que mensura a posse de eletrodomésticos e eletrônicos (pouco mais de 60\%), com computadores conectados à internet (39\%), com um ou dois veículos (60\%) e com renda total per capita acima de dois salários-mínimos (35\%). A maioria dos domicílios apresenta baixa fecundidade (dois filhos) e poucos moradores (até quatro). As estratégias de fecundidade são, portanto, parte de um sistema orientado pela reprodução social (minimização dos riscos de dilapidação do patrimônio familiar) ou ascensão social (acumulação de recursos ao longo de gerações).

Diferentemente, tais domicílios são fracamente dotados de capital cultural em termos dos indicadores construídos: em somente $32 \%$ deles, a escolaridade máxima

17. Ver também Bertoncelo (2010). 
do chefe e/ou cônjuge alcança o ensino médio completo (em cerca de $42 \%$ deles, a escolaridade máxima não passa do fundamental - ginásio - incompleto). Essa relativa destituição de capital escolar reproduz, em parte, o que ocorre na origem dos domicílios: em $85 \%$ deles, a escolaridade máxima não chega aos oito anos de estudos completos (mesmo quando consideramos pais e mães do chefe e do cônjuge separadamente).

Essa situação de desqualificação escolar relativa estende-se a indicadores de capital cultural (quase inexistência de domicílios com chefe e/ou cônjuges que fizeram ou fazem cursos de idiomas, pré-escola ou jardim de infância), com exceção dos cursos profissionalizantes ou técnicos. No entanto, é provável que a destituição relativa de capital cultural se conjugue a estratégias de investimento em capital escolar (e possivelmente em outras formas de capital cultural) dos filhos: há uma proporção acima da média nesses domicílios de filhos com ensino superior e também de filhos da mesma família que estudam em escolas privadas e públicas, o que pode indicar que tais estratégias de investimento educativo coexistam com estratégias de reprodução do patrimônio econômico da família (sobretudo da empresa familiar) que dependem relativamente menos da reconversão do capital econômico em credenciais escolares.

\section{Zona 5 - Empregados de escritório e não manuais qualificados}

Essa zona do espaço social, que inclui cerca de 6\% dos domicílios (e de indivíduos), ocupa uma região homóloga à anterior quanto ao primeiro eixo, mas oposta em relação ao segundo e ao terceiro, evidenciando as diferenças especialmente na estrutura do capital e na origem social. Os domicílios nessa zona caracterizam-se por níveis relativamente mais elevados de capital cultural do que de capital econômico e são socialmente recrutados das frações mais e menos qualificadas de trabalhadores manuais urbanos e da fração mais capitalizada de autoempregados urbanos, evidenciando que essa zona é um ponto de chegada para muitos indivíduos, oriundos de outras regiões, com estratégias de acumulação de capital (a partir das frações manuais) ou de reconversão de sua estrutura (a partir da fração autoempregada mais capitalizada).

O pertencimento de classe ocupacional mais frequente é a de trabalhadores não manuais de rotina e de técnicos de nível médio (37\%), com uma proporção acima da média de quadros administrativos médios (17\% ante 5,3\% na amostra) e profissionais (10,3\% ante 5,9\%) - pertencimentos de classe igualmente marcante para os cônjuges com ocupação. Os domicílios são dotados de capital escolar relativamente elevado. Em quase 70\% deles, o chefe e/ou o cônjuge alcançaram o ensino superior, sendo que, em 62,5\%, a escolaridade máxima é o ensino superior incompleto. Essa 
relativa qualificação em termos de credenciais escolares revela-se quase sempre como um prolongamento de trajetórias educativas a partir de origens relativamente menos destituidas em termos de capital escolar: a escolaridade máxima do domicílio na origem alcança o ensino médio completo em cerca de $25 \%$ dos casos (com uma proporção bem acima da média amostral de pais/mães de chefes/cônjuges que alcançaram o ensino superior). Essa maior dotação em termos de capital escolar na origem reflete-se, ainda, no melhor perfil de escolaridade entre os irmãos de chefes e/ou cônjuges (a proporção de chefes nessa zona que têm algum irmão ou irmã com ensino superior atinge 31\%; entre os cônjuges, essa proporção é de 24\%).

Em relação a outras formas de capital cultural, aqui os domicílios possuem escores relativamente elevados em algumas de suas modalidades indicativas: em quase $82 \%$ deles, chefe e/ou cônjuge estudaram em escola privada ou federal, o que aumenta, segundo a literatura, o chamado "capital informacional" que pode ser mobilizado na construção de trajetórias educativas "bem-sucedidas" das gerações mais novas (Bonaldi, 2015). De fato, são mais frequentes nesses domicílios os filhos com ensino superior ( $13 \%$ ante $8 \%$ ) e de filhos residentes nos domicílios que estudam apenas em escolas privadas (cerca de $25 \%$ ante $10 \%$ ). Em $61 \%$ deles, o chefe e/ou o cônjuge fizeram pré-escola ou jardim de infância e, em $56 \%$, o chefe e/ou o cônjuge fizeram ou fazem curso de computação. São também mais comuns, embora ainda pouco frequentes, os domicílios em que o chefe e/ou o cônjuge fizeram ou fazem curso de idiomas (19\%).

Em termos de recrutamento social, como vimos, essa zona é bastante heterogênea, revelando a existência, na origem desses domicílios, de estratégias familiares de reconversão de capital (cerca de 23\% dos domicílios têm origem na zona do espaço ocupada pela pequena burguesia descrita anteriormente) ou de estratégias de investimentos na acumulação de capital cultural a partir de origens sociais menos privilegiadas (cerca de 30\% dos domicílios têm origem entre trabalhadores manuais qualificados e outros $17 \%$, entre autoempregados precarizados). Há também uma proporção menor de recrutamento interno a essa zona: cerca de $8 \%$ dos domicílios têm origem entre as frações gerenciais ou não manuais de rotina (entre os cônjuges, $15,7 \%$ têm origem nessas frações, embora o peso da origem na pequena burguesia seja menor do que no caso dos chefes $)^{18}$.

Essa zona do espaço social é caracterizada por certa qualificação em termos de capital econômico, embora seja fracamente dotada de patrimônio (possivelmente

18. É provável que esses níveis relativamente elevados de mobilidade social entre gerações que caracterizam esta região do espaço se conjuguem a níveis elevados de mobilidade intrageracional, pois há uma proporção relativamente elevada de chefes e/ou cônjuges entre 25 e 34 anos de idade. 
como resultado de esforços de reconversão de capital econômico na origem ou de investimento na acumulação de capital cultural que marcam a ascensão social dos chefes e cônjuges dos domicílios aí localizados). Cerca de 34\% dos domicílios possuem renda per capita total entre dois e cinco salários-mínimos (ante 18\% na amostra), $58 \%$ possuem computador com acesso à internet, $47 \%$ contam com um veículo automotor, mas é abaixo da média a proporção de domicílios que contam com empregadas domésticas ou diaristas.

Os domicílios são, em geral, bem equipados: quase $72 \%$ deles têm escores médio-alto ou alto no índice que mensura a existência de eletrodomésticos ou eletrônicos. Nessa zona, é relativamente mais frequente morar em apartamentos (25\% ante $11 \%$ ) ou condomínios residenciais (38\% ante 20\%), com três cômodos (43\%) e dois banheiros (19\%). A condição da habitação é boa em quase $90 \%$ dos casos. Também são relativamente frequentes aqui os domicílios com poucos moradores (24\% têm apenas dois moradores), com baixa fecundidade (com nenhum ou apenas um filho) e com algum rendimento financeiro (36\%), esforço de poupança que provavelmente se conjuga a esse componente de investimento no prolongamento das trajetórias educativas da geração mais nova (e, portanto, a um esforço familiar de ascensão social).

Por fim, sublinho um aspecto dos padrões de sociabilidade e interação nessa zona do espaço social, que possivelmente corroboram um achado de estudos qualitativos de mobilidade social (Bertaux e Thompson, 2007), de que movimentos de ascensão social tendem a levar à estigmatização de componentes referentes à origem social (bairro, amigos, gostos etc.) e à construção de novos pertencimentos dentro dos grupos de referência: a proporção de melhores amigos com pertencimento às frações profissionais (quase 10\%), proprietárias (4,5\%), gerenciais $(3,4 \%)$ ou não manuais de rotina $(14,7 \%)$ é relativamente elevada se considerarmos as proporções amostrais (e o peso relativo das frações de que são recrutados os chefes e cônjuges) e são abaixo da média as proporções de melhores amigos que pertencem a frações manuais qualificadas $(6,5 \%)$ ou não qualificadas $(3,1 \%)$.

\section{Zona 7 - Forte patrimonialização na origem social e estratégias (malsucedidas) de reconversão dos capitais herdados}

Essa zona inclui uma porção relativamente pequena dos domicílios (e indivíduos) da amostra considerada, quase 6\%. Tais domicílios são profundamente heterogêneos em termos do pertencimento de classe ocupacional de chefes e/ou cônjuges, embora as proporções de quadros administrativos médios (gerentes e supervisores de trabalho não manual, 9,5\%), supervisores de trabalho manual (6\%), autoempre- 
gados mais capitalizados (12\%) e empregadores urbanos (4,8\%) sejam relativamente elevadas diante das proporções amostrais.

A propriedade que mais fortemente estrutura essa zona do espaço social é a peculiaridade do pertencimento à classe ocupacional de origem do domicílio: quase $75 \%$ dos domicílios têm origem nas frações da pequena ou média burguesia urbana; 30\%, na fração de pequenos ou médios empregadores urbanos (e mais: quase 45\% dos domicílios com esse pertencimento de origem estão aqui localizados); outros $18 \%$, na pequena burguesia não proprietária (autoempregados mais capitalizados); 12\%, entre autoempregados menos capitalizados.

Não é apenas o pertencimento de classe na origem que estrutura essa zona do espaço social, mas também a forte patrimonialização do capital econômico na origem, se levarmos em conta os dados disponíveis para a construção dos indicadores pertinentes: são elevadíssimas as proporções de chefes e/ou cônjuges que viviam em domicílios, quando jovens ( 15 anos de idade), em que alguém possuía um veículo de trabalho (67\% ante $11 \%$ na amostra), era dono ou sócio de uma empresa ( $80 \%$ ante $18 \%$ ), possuía veículo de passeio ( $85 \%$ ante $23 \%$ ), possuía uma casa de veraneio (56\% ante $9 \%$ ), uma propriedade para alugar (52\% ante 9\%) ou um terreno/sítio (66\% ante 30\% na amostra). É também bastante significativa a proporção dos que afirmaram viver em habitações próprias nessa idade (quase 100\%). Essas proporções são significativamente menores quando o capital econômico em sua dimensão patrimonial é mensurado sincronicamente (ainda que estejam acima da média amostral): $19 \%$ dos domicílios possuem um veículo de trabalho; $16 \%$, sítio, fazenda ou terreno; 16\%, uma empresa; 9\%, uma casa secundária (de veraneio). Não deixa de ser significativa a proporção dos domicílios com computador conectado à internet (42\%), com dois veículos ou mais (17\%), com rendimentos financeiros derivados de poupança (33\%) ou aplicações (7,6\% ante 3,6\%), com rendimento total per capita acima de três salários-mínimos (20,3\% ante 10,5\%), com empregadas domésticas ou diaristas (12\%) e com valores médio-alto e alto no índice que mensura a presença de eletrodomésticos e eletrônicos (cerca de 65\%). As condições de habitação também parecem ser razoavelmente adequadas: predominam os apartamentos e condomínios regularizados, classificados como tendo boa conservação em quase $80 \%$ dos casos.

Os domicílios são relativamente menos dotados de capital cultural. Quanto às credenciais escolares, em cerca de 30\% dos domicílios o chefe e/ou cônjuge possui, ao menos, o ensino médio completo, que é uma proporção menor do que a dos domicílios localizados na zona 5 (significativamente menos estruturada em torno da posse de capital econômico sob a forma de patrimônio), o que tipicamente reproduz (portanto, não amplia) a dotação de capital escolar na origem (sendo 29,5\% a proporção de domicílios com a escolaridade máxima similar na origem). Essa dotação 
de credenciais escolares intermediárias reflete-se na escolaridade máxima alcançada pelos irmãos do chefe e/ou cônjuge.

Portanto, se houve uma reprodução mais ou menos bem-sucedida em termos de credenciais escolares (que se mantiveram em níveis intermediários), ocorreu comparativamente uma relativa perda de capital econômico (possivelmente relacionada com a divisão do patrimônio familiar entre gerações). No entanto, é notável que $a$ origem relativamente privilegiada dos domicilios nessa zona se reflita na dotação relativamente maior de capital econômico em termospatrimoniais, financeiros ou monetários do que nos domicilios localizados na zona 5 e mesmo na zona 6 (que descrevemos a seguir), significativamente mais ricos em capital cultural, mas com origens menos privilegiadas. Há, portanto, indícios fortíssimos de que os condicionamentos associados a uma posição no espaço social não se reduzem a suas propriedades relacionais observadas apenas de uma perspectiva sincrônica.

\section{Zona 6 - Profissionais ascendentes e frações não manuais estabelecidas}

Essa zona, que inclui cerca de 6,5\% dos domicílios (e 5,3\% dos indivíduos), está fortemente estruturada em torno do pertencimento às frações profissionais (33\%), gerenciais (19\%) e não manuais de rotina (18\%), com origem nas frações de classe não manuais de rotina e gerenciais $(28,2 \%$ ante $8 \%$ na amostra) e na pequena burguesia urbana não proprietária (autoempregados mais capitalizados, 13,7\% ante $6,7 \%$ na amostra). Entre os cônjuges, o peso da origem nas frações não manuais e gerenciais é igualmente elevado, assim como o peso da origem nas frações profissionais e dirigentes ( $4,8 \%$ ante $2,6 \%$ na amostra).

O recrutamento a essa zona é, portanto, estruturado por estratégias de acumulação de capital cultural a partir das frações não manuais e/ou de reconversão da composição do capital a partir da pequena burguesia urbana. Esse argumento ganha força quando consideramos outra propriedade que estrutura fortemente essa zona do espaço social: a elevadíssima qualificação em termos de credenciais escolares e outras medidas de capital cultural acumulado nos domicílios. Em quase $80 \%$ dos domicílios, a escolaridade máxima do chefe e/ou cônjuge alcança o ensino superior completo; em 86\% deles, chefe e /ou cônjuge estudaram em escolas privadas/federais, e são também mais frequentes os domicílios em que chefe e/ou cônjuge fizeram ou fazem cursos de idiomas (22\% ante 6\%). A maior qualificação relativa em termos de qualificação educacional reflete-se na maior proporção entre irmãos/irmãs de chefes e/ou cônjuges com ensino superior (entre os irmãos do chefe, essa proporção atinge 46\%).

A estratégia de acumulação de capital cultural que estrutura essa zona do espaço social é fortemente evidenciada quando comparamos o perfil de escolarização que 
está na origem desses domicílios, tipicamente, como vimos, oriundos de frações não manuais e da pequena burguesia não proprietária: em quase 34\% dos domicílios, a escolaridade máxima alcançada pelos pais de chefe e/ou cônjuge não passou do ensino médio completo, que é a maior proporção encontrada na amostra de domicílios com esse perfil educacional na origem (e esse argumento vale se considerarmos separadamente as credenciais escolares dos pais do chefe e do cônjuge). É provável que a modalidade de apropriação de capital que caracteriza a trajetória desses domicílios seja reproduzida nas gerações mais novas: são frequentes os domicílios em que os filhos alcançaram o ensino superior (16,5\% ante $8 \%$ na amostra - lembremos que esse dado se refere apenas aos filhos residentes no domicílio e, portanto, é insuficiente para caracterizar adequadamente as estratégias de transmissão de herança material e imaterial levadas a cabo pelas famílias) e que estudam ou estudaram em escolas privadas ( $31 \%$ ante $10 \%$ na amostra). Há evidências, portanto, de que as estratégias de acumulação de capital (e, portanto, de ascensão social) atravessem várias geraçôes familiares.

Os padrões de sociabilidade são razoavelmente estratificados: entre os cônjuges e melhores amigos (quando foi possível identificar a categoria ocupacional), predominam os que estão inseridos nas frações profissionais, gerenciais e não manuais de rotina (as proporções são bastante similares para chefes e cônjuges no que se refere à classe ocupacional do melhor amigo). No entanto, é importante notar que o peso que têm as frações profissionais e dirigentes no recrutamento de amigos e cônjuges é desproporcional a seu peso na origem desses domicílios (por exemplo, entre os chefes, apenas 1,7\% têm origem nessas frações de classe, mas 14,7\% têm melhores amigos nessas mesmas frações, ante 4,8\% na amostra). Ou seja, é possível que o movimento de ascensão pelo espaço social que caracteriza fortemente os indivíduos e famílias nesses domicílios conjugue uma estratégia de acumulação de capital cultural com uma de acumulação de capital social.

Por fim, cabe explorar brevemente outra propriedade que caracteriza essa zona, que é a qualificação relativamente elevada em termos de capital econômico dos domicílios, embora com fraca patrimonialização (resultante provavelmente dos esforços de acumulação de capital cultural e de reconversão da estrutura do capital que estão em suas origens). Quase 45\% dos domicílios possuem renda total per capita acima de três salários-mínimos, 54\% estão na categoria mais elevada do índice que mensura a existência de eletrodomésticos e eletrônicos, 30\% contam com uma empregada doméstica ou diarista (ante $9 \%$ na amostra), $71 \%$ têm computador com conexão à internet (ante 27\%) e 40\% contam com algum rendimento financeiro (poupança). As habitações têm geralmente condições boas de conservação (90\%) e são amplas (28\% com cinco ou mais cômodos). São mais numerosas as habitações 
em apartamentos (29\%) e condomínios (36\%). O patrimônio acumulado nesses domicílios restringe-se geralmente à posse de um veículo (61\%) e a propriedade da habitação em que reside a família. São muito raros (abaixo mesmo das já diminutas proporções médias encontradas na amostra) os domicílios que possuem uma casa secundária, propriedade para alugar (3\% ante quase 6\% na amostra), sítio/terreno ou a propriedade de capital produtivo (esta última informação indica que lidamos aqui com frações predominantemente assalariadas).

Zonas 8 e 9 - Frações profissionais, dirigentes e proprietárias com elevada patrimonialização do capital e com origens sociais muito privilegiadas

As zonas 8 e 9 , que incluem - em proporções similares - cerca de $6 \%$ dos domicílios (e 5\% dos indivíduos), serão descritas conjuntamente porque têm uma propriedade distintiva em comum: são fortemente estruturadas em torno da transmissão de elevado patrimônio familiar e pelos privilégios na reprodução de capital cultural, econômico e social. Os domicílios em ambas as zonas são caracterizados por elevados níveis de capital patrimonial na origem - as proporções de domicílios em que o chefe e/ou o cônjuge, quando jovens, possuíam uma casa de veraneio, propriedade para alugar, terreno/sítio ou veículo de passeio são elevadíssimas - ou alguma forma de capital produtivo (propriedade de empresas). Essa origem fortemente privilegiada, como veremos, reproduz-se na forte dotação desses domicílios em termos de capital econômico e cultural, de uma perspectiva sincrônica. Em outras palavras, essas zonas concentram volumes elevadíssimos de capital que, ao menos em parte, foram transmitidos pelas gerações anteriores nas famílias do chefe e/ou do cônjuge.

Os domicílios em ambas as zonas guardam também muita similaridade em termos do pertencimento de classe ocupacional de chefes e/ou cônjuges, mas com algumas diferenças relevantes. Na zona 8 , destacam-se os pertencimentos às frações profissional (39,4\% ante 5,3\%), dirigente (4,8\% ante 0,6\% na amostra), gerencial (7,9\% contra $5,3 \%)$ e proprietária (empregadores com mais de 5 empregados, $12,7 \%$ ante $1,2 \%)$. Destaca-se, entre os cônjuges com ocupação, o pertencimento à fração não manual de rotina (41,4\% ante $15,5 \%$, maior proporção na amostra). Deve-se notar, ainda, a proporção relativamente elevada de domicílios em que algum morador possui ou é sócio em empresa (quase 50\%), evidenciando aqui a fluidez entre o assalariamento, o autoemprego especializado e a condição de empregador nessa zona do espaço social. Na zona 9, destacam-se os pertencimentos às frações profissional (29,5\%), dirigente (2,1\%), gerencial (11,6\%), não manual de rotina (15,8\% ante $8,3 \%$ ) e às frações da pequena e média burguesia urbana (pequenos empregadores 
urbanos, 6,8\%, e médios empregadores urbanos, 7,5\% ${ }^{19}$. Mais de $50 \%$ dos cônjuges (com ocupação) têm esses mesmos pertencimentos de classe ocupacional, o que revela certa homogeneidade de classe no domicílio. Há igualmente uma proporção elevada de domicílio em que algum morador possui ou é sócio de empresa $(33 \%)^{20}$.

Tais zonas são, ainda, igualmente estratificadas em termos dos padrões de interação e sociabilidade (ao menos conforme os indicadores aqui empregados): encontram-se aqui as proporções mais elevadas de domicílios (quase 35\%) em que os melhores amigos de chefes/cônjuges são profissionais, dirigentes/gerentes ou empregadores $^{21}$. Encontram-se também as proporções mais elevadas de chefe/cônjuges que se autodeclaram brancos e que declaram que seus melhores amigos são brancos (proporções acima de $70 \%$ dos domicílios).

O que distingue os domicílios de uma zona e outra é o peso das dimensões material e imaterial da herança familiar herdada, que provavelmente reflete diferenças nas modalidades de apropriação do capital. Os domicílios na zona 9, relativamente mais próxima ao centro do segundo eixo (e à direita do terceiro), são fortemente estruturados em torno da transmissão de capital cultural, ao menos em termos de credenciais escolares, e pela origem associada a um pertencimento de classe especifico. Assim, em mais de 90\% dos domicílios nessa zona, pais e/ou mães de chefe e/ou cônjuge alcançaram o ensino superior (na amostra, essa proporção é de pouco mais que 6\%). De longe, essa é a zona que concentra os domicílios com origem social, em termos de credenciais escolares, mais privilegiada (o argumento é válido mesmo quando consideramos separadamente as credenciais escolares de pais e mães de chefe e cônjuge separadamente). Essa herança imaterial se reproduz no capital escolar do domicílio (em mais de $80 \%$ deles, a escolaridade máxima alcança o ensino superior) e em outros indicadores de capital cultural (em cerca de $85 \%$ dos domicílios, chefe e/ ou cônjuge estudaram em escolas privadas/federais; em $42 \%$, fazem ou fizeram curso de idiomas; em quase 17\%, é possível encontrar um chefe ou cônjuge que tenha feito ou esteja fazendo um curso de música ou de arte, uma proporção significativamente acima da encontrada na amostra, que é de 2,3\%; há também proporções bem acima da média de irmãos e irmãs de chefes e/ou cônjuges que alcançaram o ensino superior, em cerca de $65 \%$ dos domicílios).

19. As diferenças de pertencimento de classe ocupacional (e outras que serão descritas) talvez possam ser explicadas pelas diferenças das fases biográficas que caracterizam chefes e cônjuges nesses domicílios. $\mathrm{Na}$ zona 8, quase 50\% dos domicílios são chefiados por indivíduos entre 45 e 64 anos, contra $15 \%$ na zona 9.

20. Há tipos frequentes de domicílios nesta zona em que o chefe pertence às frações profissional ou proprietária e o cônjuge (quando ocupado), à fração profissional ou gerencial.

21. Estas zonas são caracterizadas pelas menores frequências relativas de não respostas (respectivamente, $31,7 \%$ e $38,1 \%$, ante $51,1 \%$ na amostra) à questão sobre "melhores amigos", especialmente no caso dos chefes. 
E o que é mais interessante: essa elevada dotação em termos de capital cultural no domicílio é evidenciada quando observamos os indicadores separadamente para chefes e cônjuges, ou seja, ambas as linhagens são portadoras de elevado capital cultural e de outras vantagens associadas à origem (relativa homogeneidade de recrutamento social), o que provavelmente aumenta as chances de sucesso das estratégias de reprodução de capital cultural nas gerações mais novas. Essas propriedades distintivas decorrem da modalidade típica de apropriação do capital (as trajetórias modais) dos indivíduos e famílias que ocupam essa zona do espaço social, que têm origem - em termos do pertencimento de classe de pais/mães de chefe e/ou cônjuges - predominantemente nas frações profissional e dirigente (65\%) e na fração de gerentes e supervisores de trabalho não manual (8\%). Quando considerados separadamente, os indicadores de origem de classe de chefe e cônjuge, o peso relativo dessas frações é mais elevado para os chefes do que para os cônjuges. Evidencia-se aqui o peso das estratégias de reprodução (e também de ascensão social) baseadas na transmissão de capital cultural, estratégia, diga-se de passagem, relativamente bem-sucedida se levarmos em conta os pertencimentos de classe mais frequentes nesses domicílios e seus escores nos indicadores de capital econômico aqui empregados (apenas como exemplo, $74 \%$ dos domicílios possuem computador conectado à internet; $67 \%$, valor mais elevado no indicador que mensura a posse de eletrodomésticos e eletrônicos; $30 \%$, mais de três salários-mínimos per capita de renda total; $25 \%$, dois veículos de passeio ou mais; 44\%, empregada doméstica ou diarista; $31 \%$ das habitações têm cinco ou mais cômodos).

Diferentemente, os domicílios na zona 8 são estruturados em torno da posse de capital econômico sob a forma de patrimônio e pela origem, em termos de classe ocupacional, nas frações gerencial $(23,8 \%$ e $11,6 \%)$ e proprietária com ou sem empregados (26,5\% e 38\%) - para chefe e cônjuge, respectivamente. Devido ao peso dessas frações de classe na origem dos domicílios, encontramos aqui níveis significativamente menores, em comparação com a zona 9 (mas ainda assim elevados), de capital cultural transmitido pelas linhagens paterna e materna de chefes e cônjuges: apenas em 37\% dos domicílios, a escolaridade máxima na origem alcança o ensino médio (em 18\%, alcança o superior) e, em mais de $40 \%$ deles, não alcança o fundamental completo (os valores são similares quando tomamos os indicadores de escolaridade na origem de chefe e cônjuge). Ainda assim, é possível notar a existência de estratégias de acumulação de capital cultural ao longo do tempo, que se expressam na maior dotação em termos de capital cultural desses domicílios se comparados à origem (em 78\% dos domicílios, a escolaridade máxima alcança o ensino superior completo; em $47 \%$, encontramos um chefe e/ou cônjuge que fez ou faz curso de idiomas) e nos esforços de transmissão de capital cultural para 
as gerações mais novas (em 27\% dos domicílios, há filhos residentes com ensino superior $)^{22}$.

É possível que o maior peso do patrimônio na estrutura do capital nos domicílios nessa zona, em comparação com a zona 9 (mais marcada, como vimos, pelo peso do capital cultural, embora também relativamente rica em capital patrimonial, se considerarmos as demais zonas, com exceção daquela da pequena burguesia urbana), reflita essa peculiaridade no processo de recrutamento social dos indivíduos e das famílias que nela se localizam. De fato, é nessa zona que o peso do patrimônio na estrutura do capital se evidencia mais intensamente, o que significa que os domicílios aí localizados apresentam valores nos indicadores de posse de patrimônio que ultrapassam em larga medida os escores encontrados em outras zonas do espaço social: assim, quase $55 \%$ (ante 5,8\% na amostra) dos domicílios nessa zona contam com uma casa de veraneio; $41 \%$, com sítio, terreno ou fazenda (ante 9\%); 44\%, com propriedade para alugar (ante 6\%); em quase 48\% deles, algum residente possui uma empresa ou é sócio de uma (essa proporção só é ultrapassada na zona 3); $50 \%$ contam com dois veículos ou mais. As habitações - em que predominam os apartamentos (51\%) - são amplas (46\% têm cinco cômodos ou mais). E mais: além do peso desproporcional do patrimônio na estrutura do capital desses domicílios, destacam-se os rendimentos de natureza financeira e monetária: em quase 46\% desses domicílios, há rendimentos financeiros decorrentes de investimento no mercado de ações (ante apenas 3,6\%); em 60\%, os rendimentos totais per capita ultrapassam cinco salários-mínimos (ante $4,22 \%)$. De fato, em termos de qualquer indicador de capital econômico, esses domicílios se distinguem muito fortemente de quaisquer outros localizados em zonas diferentes: 70\% contam com a presença de empregada doméstica ou diarista; 85\%, com computador conectado à internet; mais de $82 \%$ alcançam o valor mais elevado no índice que mensura a posse de eletrodomésticos e eletrônicos.

\section{Conclusão}

Nesta exposição, procurei reconstruir indutivamente as fronteiras que separam conjuntos de agentes com posições relativas distintas no espaço social e que conformam os padrões de sociabilidade e interação social. Uma estratégia operacional desse tipo parte da observação da distribuição das múltiplas formas de capital (as propriedades relacionais ativas) e "chega" à dimensionalidade empírica do espaço social. Obviamen-

22. Notemos que, em $25 \%$ dos domicílios dessa zona, chefe e cônjuge são pós-graduados, proporção maior do que a média amostral (em torno de 2\%), seguida apenas de longe pelos domicílios nas zonas 6 e 9 , em que essa proporção atinge $17 \%$ para os chefes. 
te, um exercício dessa natureza é muito sensível aos indicadores utilizados e, portanto, esbarra em muitas limitações quando se vale de fontes secundárias.

O exercício aqui proposto é bastante incomum nos estudos de classe nacionais e internacionais que, em geral, empregam um esquema de posições de classe, definidas com base em critérios teoricamente informados (relações de emprego, da perspectiva neoweberiana; direitos de apropriação do excedente, da perspectiva neoweberiana) e delimitadas a priori. Por isso, essas posições assemelham-se a agregados ocupacionais (Crompton, 2003).

A meu ver, uma estratégia indutiva deixa entrever como as fronteiras de classe (entre posiçôes relativas vizinhas no espaço social) são continuamente reproduzidas, disputadas e redesenhadas na prática social: as estratégias de reprodução confrontam-se com estratégias de usurpação, acumulação ou reconversão de capitais, em que estão em jogo as taxas de conversão e de retorno dos capitais (por exemplo, credenciais escolares) possuidos pelos agentes e o valor dos capitais relevantes nos diferentes campos em que a vida social se organiza.

\section{Apêndice}

TABELA 1

Frequência Absoluta e Relativa das Modalidades Ativas

\begin{tabular}{|c|c|c|}
\hline \multicolumn{3}{|c|}{ Renda domiciliar per capita (em salários mínimos) } \\
\hline MODALIDADES & $\mathrm{N}$ & $\%$ \\
\hline $1 / 2 \mathrm{sm}-$ & 1575 & 28,91 \\
\hline $1 / 2-1 \mathrm{sm}$ & 1195 & 24,30 \\
\hline $1-2 \mathrm{sm}$ & 951 & 20,61 \\
\hline $2-3 \mathrm{sm}$ & 303 & 6,62 \\
\hline $3-5 \mathrm{sm}$ & 250 & 5,23 \\
\hline $5 \mathrm{sm}+$ & 187 & 4,22 \\
\hline \multicolumn{3}{|c|}{ Condição de ocupação do domicílio } \\
\hline Modalidades & $\mathrm{N}$ & $\%$ \\
\hline Alugado & 1113 & 24,02 \\
\hline Próprio & 3240 & 64,37 \\
\hline Outros & 557 & 11,61 \\
\hline \multicolumn{3}{|c|}{ Domicílio conta com empregado doméstico ou diarista } \\
\hline Modalidades & $\mathrm{N}$ & $\%$ \\
\hline EDOM- & 4461 & 90,42 \\
\hline EDOM+ & 432 & 9,26 \\
\hline
\end{tabular}


O espaço das classes sociais no Brasil, pp. 73-104

\begin{tabular}{|c|c|c|}
\hline \multicolumn{3}{|c|}{ Alguém no domicílio possui uma empresa (dono ou sócio) } \\
\hline Modalidades & $\mathrm{N}$ & $\%$ \\
\hline EMP- & 4339 & 88,18 \\
\hline EMP+ & 571 & 11,82 \\
\hline \multicolumn{3}{|c|}{ Alguém no domicílio possui um veículo de trabalho } \\
\hline Modalidades & $\mathrm{N}$ & $\%$ \\
\hline VTRAB- & 4575 & 92,50 \\
\hline VTRAB+ & 335 & 7,50 \\
\hline \multicolumn{3}{|c|}{ Alguém no domicílio possui uma segunda casa (casa de campo, de veraneio) } \\
\hline Modalidades & $\mathrm{N}$ & $\%$ \\
\hline CSEC- & 4615 & 94,22 \\
\hline CSEC + & 295 & 5,78 \\
\hline \multicolumn{3}{|c|}{ Alguém no domicílio possui propriedade para alugar } \\
\hline Modalidades & $\mathrm{N}$ & $\%$ \\
\hline PALUGA- & 4618 & 94,07 \\
\hline PALUGA + & 292 & 5,93 \\
\hline \multicolumn{3}{|c|}{ Índice de rendimentos financeiros* } \\
\hline Modalidades & $\mathrm{N}$ & $\%$ \\
\hline Financeiro0 & 3514 & 72,26 \\
\hline Financeiro1 & 1231 & 24,07 \\
\hline Financeiro2 & 165 & 3,66 \\
\hline \multicolumn{3}{|c|}{ Quantidade de carros ou motos no domicílio } \\
\hline Modalidades & $\mathrm{N}$ & $\%$ \\
\hline Veículo0 & 3074 & 59,36 \\
\hline Veículo1 & 1402 & 30,26 \\
\hline Veículo2+ & 434 & 10,38 \\
\hline \multicolumn{3}{|c|}{ Domicílio possui computador conectado à internet } \\
\hline Modalidades & $\mathrm{N}$ & $\%$ \\
\hline Internet- & 3672 & 72,90 \\
\hline Internet+ & 1238 & 27,10 \\
\hline \multicolumn{3}{|c|}{ Classe de pertencimento ocupacional do domicílio** } \\
\hline Modalidades & $\mathrm{N}$ & $\%$ \\
\hline PRF_QAS & 277 & 5,89 \\
\hline QAM & 255 & 5,25 \\
\hline TNR-TEC & 567 & 11,25 \\
\hline STM & 204 & 4,37 \\
\hline TMQ & 606 & 12,69 \\
\hline TMNQ & 847 & 18,12 \\
\hline $\mathrm{CP}+$ & 490 & 9,37 \\
\hline $\mathrm{CP}-$ & 1067 & 21,58 \\
\hline AGR & 475 & 8,72 \\
\hline EMPUR & 122 & 2,76 \\
\hline
\end{tabular}




\begin{tabular}{lcc}
\hline & Origem de classe ocupacional ${ }^{* * *}$ & \\
\hline MODALIDADES & $\mathrm{N}$ & $\%$ \\
\hline OPRF-QAS & 137 & 3,02 \\
OQAM & 205 & 3,63 \\
OTNR-TEC & 200 & 3,90 \\
OTMQ & 562 & 11,84 \\
OTMNQ & 593 & 12,18 \\
OCP+ & 308 & 6,15 \\
OCP- & 717 & 14,21 \\
OTAGR & 260 & 6,62 \\
OCPGR-EMPR (trabalhadores, autoempregados e empregadores rurais) & 1353 & 26,03 \\
OEMPUR & 175 & 3,90 \\
\hline
\end{tabular}

${ }^{*}$ Corresponde a uma simples soma da presença de rendimentos derivados de caderneta de poupança e/ou de aplicações financeiras. Em quase 100\% dos casos, a categoria financeirol equivale à presença de algum morador no domicílio que possui caderneta de poupança.

** PRF_QAS (profissionais e dirigentes - inclui detentores de ocupaçōes credenciais, como advogados, engenheiros, médicos, economistas, administradores etc. e diretores ou dirigentes de empresas); QAM (quadros administrativos médios por título ocupacional - gerentes, chefes, supervisores - ou por exercício efetivo de supervisão de trabalho não manual); TNR-TEC (trabalhadores não manuais de rotina e técnicos de nível médio); STM (supervisores de trabalho manual); TMQ (trabalhadores manuais qualificados); TMNQ (trabalhadores manuais não qualificados); $\mathrm{CP}+$ (autoempregados capitalizados - $\mathrm{o}$ indicador de capitalização é a posse de licença ou permissão para exercício do trabalho); CP- (autoempregados não capitalizados ou não formalizados, sem licença para exercício da atividade); AGR (trabalhadores ou autoempregados no campo); EMPUR (empregadores urbanos - há um número muito reduzido de empregadores agrícolas aqui alocados). As análises feitas no estudo utilizam uma versão mais desagregada do esquema, com quinze categorias (separando profissionais e dirigentes, trabalhadores não manuais de rotina e técnicos, pequenos empregadores urbanos - com quatro empregados ou menos - e médios empregadores urbanos - com cinco empregados ou mais, e empregadores rurais).

*** Para diferenciar as categorias "OCP+" e "OCP-", utilizou-se um indicador de capitalização diferente daquele empregado para diferenciar essas mesmas categorias da classe ocupacional do domicílio (posse de licença). Neste caso, empregou-se um indicador de supervisão de trabalho de outras pessoas. A condição de autoemprego com exercício de supervisão do trabalho de outra(s) pessoa(s) foi tomado como um indicador de capitalização (quase desnecessário dizer, impreciso).

\begin{tabular}{lcc}
\hline \multicolumn{3}{c}{ Escolaridade máxima do domić́lio (escolaridade máxima de chefe e/ou cônjuge) } \\
\hline MODALIDADES & $\mathrm{N}$ & $\%$ \\
\hline SUP (ensino superior completo) & 507 & 11,70 \\
SUP- (ensino superior incompleto) & 275 & 5,57 \\
EM (ensino médio - colegial - completo) & 1363 & 27,67 \\
FUND+ (fundamental - ginásio - completo) & 842 & 16,01 \\
FUND (fundamental incompleto / primário completo) & 1263 & 25,63 \\
FUND- (fundamental / primário incompleto) & 519 & 10,56 \\
NFRE (nunca frequentou escola) & 141 & 2,87 \\
\hline$\quad$ Escolaridade máxima na origem do domicílio (escolaridade máxima de pai/mãe do chefe/cônjuge \\
\hline MODALIDADES & $\mathrm{N}$ & $\%$ \\
\hline OSUP (ensino superior completo ou incompleto) & 287 & 6,26 \\
OEM (ensino médio / colegial completo) & 591 & 11,62 \\
OFUND+ (ginásio completo / médio incompleto) & 494 & 10,00 \\
OFUND (primário completo e ginásio incompleto) & 1522 & 31,65 \\
\hline
\end{tabular}




\begin{tabular}{|c|c|c|}
\hline OFUND- (equivale a primário incompleto) & 1016 & 19,68 \\
\hline ONFRE (não frequentou escola) & 887 & 18,68 \\
\hline \multicolumn{3}{|c|}{ Chefe e/ou cônjuge fizeram jardim de infã̃ncia ou pré-escola } \\
\hline Modalidades & $\mathrm{N}$ & $\%$ \\
\hline JINF- & 2927 & 61,25 \\
\hline JINF+ & 1983 & 38,75 \\
\hline \multicolumn{3}{|c|}{ Chefe e/ou cônjuge fizeram ou fazem curso de idiomas } \\
\hline Modalidades & $\mathrm{N}$ & $\%$ \\
\hline Língua- & 4620 & 93,62 \\
\hline Língua+ & 290 & 6,38 \\
\hline \multicolumn{3}{|c|}{ Chefe e/ou cônjuge fizeram ou fazem curso de computação } \\
\hline Modalidades & $\mathrm{N}$ & $\%$ \\
\hline COMPUT- & 4123 & 84,53 \\
\hline COMPUT+ & 787 & 15,47 \\
\hline \multicolumn{3}{|c|}{ Chefe e/ou cônjuge fizeram ou fazem curso profissionalizante (técnico) } \\
\hline Modalidades & $\mathrm{N}$ & $\%$ \\
\hline Técnico- & 3500 & 71,70 \\
\hline Técnico+ & 1410 & 28,30 \\
\hline \multicolumn{3}{|c|}{ Tipo de escola em que chefe/cônjuge estudam ou estudaram } \\
\hline Modalidades & $\mathrm{N}$ & $\%$ \\
\hline $\mathrm{PRIV} / \mathrm{FED}-$ & 3639 & 73,90 \\
\hline $\mathrm{PRIV} / \mathrm{FED}+$ & 1271 & 26,10 \\
\hline \multicolumn{3}{|c|}{ Chefe e/ou cônjuge moravam em um domicílio próprio, aos 15 anos de idade } \\
\hline Modalidades & $\mathrm{N}$ & $\%$ \\
\hline Casa_p- & 774 & 17,45 \\
\hline Casa_p+ & 4124 & 82,29 \\
\hline \multicolumn{3}{|c|}{ Chefe e/ou cônjuge moravam em um domicílio, aos 15 anos, que contava com uma propriedade para aluga } \\
\hline MODAlidades & $\mathrm{N}$ & $\%$ \\
\hline Propaluga2- & 4467 & 90,51 \\
\hline Propaluga2+ & 431 & 9,23 \\
\hline \multicolumn{3}{|c|}{ Chefe e/ou cônjuge moravam em um domicílio, aos 15 anos, que contava com uma segunda casa } \\
\hline Modalidades & $\mathrm{N}$ & $\%$ \\
\hline Casasec2- & 4425 & 90,11 \\
\hline casasec $2+$ & 473 & 9,63 \\
\hline \multicolumn{3}{|c|}{ Chefe e/ou cônjuge moravam em um domicílio, aos 15 anos, em que alguém possuía uma empresa } \\
\hline MODAlidades & $\mathrm{N}$ & $\%$ \\
\hline Empresa2- & 4003 & 81,81 \\
\hline Empresa2+ & 895 & 17,93 \\
\hline \multicolumn{3}{|c|}{ Chefe e/ou cônjuge moravam em um domicílio, aos 15 anos, que contava com um veículo de passeio } \\
\hline MODAlidades & $\mathrm{N}$ & $\%$ \\
\hline Veículo2- & 3824 & 76,70 \\
\hline Veículo2+ & 1074 & 23,04 \\
\hline
\end{tabular}


Chefe e/ou cônjuge moravam em um domicílio, aos 15 anos, que contava com um veículo de trabalho

\begin{tabular}{lcc}
\hline Modalidades & $\mathrm{N}$ & $\%$ \\
\hline Veículo_TraB2- & 4376 & 88,65 \\
Veículo_TRAB2+ & 522 & 11,09 \\
\hline
\end{tabular}

\section{Referências Bibliográficas}

Bennett, Tony et al. (2009), Culture, class distinction. Abingdon, Routledge.

Bertaux, Daniel \& Thompson, Paul. (2007), Pathways to class analysis: a qualitative approach to social mobility. New Brunswick, Transaction Publishers.

Bertoncelo, Edison. (2010), Classes sociais e estilos de vida na sociedade brasileira. Tese de doutorado, Faculdade de Filosofia, Letras e Ciências Humanas da Universidade de São Paulo. . (2013), “Classes e práticas sociais". Revista Brasileira de Ciências Sociais, 81 (28): $183-211$.

. (2015), "Social classes in Brazil: time, trajectory and immaterial inheritance". The Sociological Review, 2 (63): 451-479.

Boito Jr., A. \& Galvão, A. (org.). (2012), Politica e classes sociais no Brasil nos anos 2000. São Paulo, Alameda.

Bourdieu, Pierre. (1987), "What makes a social class? On the theoretical and practical existence of groups". Berkeley Journal of Sociology, 32: 1-17.

. (2005), O poder simbólico. Rio de Janeiro, Bertrand Brasil.

. (2007), O senso prático. Rio de Janeiro, Vozes.

. (2008), Distinção: crítica social do julgamento. São Paulo, Edusp.

Сrompton, Rosemary. (2003), Class and stratification: an introduction to current debates. Cambridge, Polity Press.

Flemmen, Magne. (2013), "Putting Bourdieu to work for class analysis: reflections on some recent contributions". The British Journal of Sociology, 2 (64): 325-343.

Le Roux, Brigitte \& Rounnet, Henry. (2010), Multiple correspondence analysis. Thousand Oaks, Sage.

Pereira, Virgílio. (2005), Classes e culturas de classe das familias portuenses. Porto, Edições Afrontamentos.

Pulici, Carolina. (2011), “O gosto dominante como gosto tradicional”. Novos Estudos Cebrap, 91: 123-139.

Ribeiro, Carlos. (2011), "Desigualdade de oportunidades e resultados educacionais no Brasil”. Dados, 1 (54): 41-87. 
Roose, Henk et al. (2012), "Culture of distinction or culture of openness? Using a social space approach to analyze the social structuring of lifestyles”. Poetics, 40: 491-513.

Santos, José. (2011), "Desigualdade de saúde no Brasil”. Revista Brasileira de Ciências Sociais, 75 (26): 28-55.

SCAlon, Celi. (2013), “Social stratification and its transformations in Brazil”. In: PEILIN, Li. et al. Handbook on social stratification in the Bric countries: changes and perspectives. Cingapura, World Scientific Publishing.

. (1999), Mobilidade social no Brasil: padrões e tendências. Rio de Janeiro, Revan/Iuperj.

Souza, Jessé. (2012), Os batalhadores brasileiros: nova classe média ou nova classe trabalhadora? Belo Horizonte, Editora UFMG.

\section{Resumo}

O espaço das classes sociais no Brasil

Este artigo tem como objetivo reconstruir o espaço das classes sociais no Brasil. Sua principal referência teórica são os estudos de classe inspirados pela perspectiva bourdieusiana, embora sejam também consideradas as potencialidades das teorias de classe weberiana e marxista. Os dados são extraídos da pesquisa Dimensões da Desigualdade Social, que contém uma amostra de mais de 8 mil domicílios. Como método de análise, o estudo combina análise de correspondências múltiplas e análise hierárquica de cluster.

Palavras-chave: Espaço social; Classe social; Capital; Desigualdade; Mobilidade social

\section{Abstract}

The space of social classes in Brazil

This paper aims at reconstructing the space of social classes in Brazil. Its main theoretical reference is based on class studies influenced by a bourdieusian perspective, although it also attempts at incorporating insights from Marxian and Weberian class theories. The data used are part of a survey called Dimensions of Social Inequality, which contains a sample of over eight thousand households. The method of analysis combines multiple correspondence analysis and hierarchical cluster analysis.

Keywords: Social space; Social class; Capital; Inequality; Social mobility.

Texto enviado em 22/1/2016 e aprovado em 2/2/2016. DoI: 10.11606/0103-2070.ts. 2016.110534 .

Edison Ricardo Bertoncelo é professor de sociologia da Faculdade de Filosofia, Letras e Ciências Humanas da Universidade de São Paulo.E-mail: edison_ricardo@uol.com.br. 